\title{
Synthesis of Higher Alcohols on Silver-promoted LaCo- and LaCoCu-Perovskites
}

\author{
Eugene V. Dokuchits* and Tatyana P. Minyukova \\ FRC «Boreskov Institute of Catalysis SB RAS» \\ Novosibirsk, Russian Federation
}

Received 22.08.2021, received in revised form 28.09.2021, accepted 03.11.2021

\begin{abstract}
LaCoO}_{3}$ and $\mathrm{LaCo}_{0.7} \mathrm{Cu}_{0.3} \mathrm{O}_{3}$ perovskites supported on highly dispersed mesoporous silica KIT-6 were impregnated with silver nitrate $\left(\mathrm{n}_{\mathrm{Ag}} / \mathrm{n}_{\mathrm{Co}}=4 / 99\right.$ and 8/99). The phase composition of the initial samples and samples after catalytic tests in syngas conversion and catalytic characteristics have been investigated. The regularities of the transformation of samples in the process of reduction in a hydrogen-containing gas have been studied. It is shown that, for the $\mathrm{LaCoO}_{3}$ sample, with an increase in the silver content, the activity and selectivity for higher alcohols increase from 6 to $23 \%$. The maximum interaction of cobalt with silver is observed at a silver content of $4 \%$. At a higher content, part of the cobalt is reduced regardless of the influence of silver due to its faster agglomeration. This leads to a stronger amorphization of the reduced sample and a sharp increase in its activity. The $\mathrm{LaCo}_{0.7} \mathrm{Cu}_{0.3} \mathrm{O}_{3}$ sample exhibits a higher selectivity for higher alcohols (36\%) due to the effect of copper. Silver promotion of the sample allows achieving the maximum selectivity for higher alcohols of $56 \%$ with a silver content of $4 \%$. A further increase in the silver content leads to a sharp decrease in the selectivity for higher alcohols $(41 \%)$ and the appearance of $\mathrm{CO}_{2}$ due to the saturation of copper-containing particles with silver and a decrease in the interaction of cobalt with copper.
\end{abstract}

Keywords: syngas conversion, synthesis of higher alcohols, silver-promoted La-Co catalysts.

Acknowledgements. This work was supported by Ministry of Science and Higher Education of the Russian Federation within the governmental order for Boreskov Institute of Catalysis (project AAAA-A21-121011390054-1). The XRD, AES studies were carried out using facilities of the shared research center «National center of investigation of catalysts» at Boreskov Institute of Catalysis. The authors are grateful to Dr. Yu. N. Bespalko for her aid in the work.

(C) Siberian Federal University. All rights reserved

This work is licensed under a Creative Commons Attribution-NonCommercial 4.0 International License (CC BY-NC 4.0).

* Corresponding author E-mail address: oschtan@catalysis.ru

ORCID: 0000-0001-9052-1413 (Dokuchits); 0000-0002-0781-9700 (Minyukova) 


\title{
Синтез высших спиртов на LaCo- и LaCoCu-перовскитах, промотированных серебром
}

\author{
Е. В. Докучиц, Т. П. Минюкова \\ Институт катализа им. Г. К. Борескова ФИЦ СО РАН \\ Российская Федерачия, Новосибирск
}

\begin{abstract}
Аннотация. Перовскиты $\mathrm{LaCoO}_{3}$ и $\mathrm{LaCo}_{0.7} \mathrm{Cu}_{0.3} \mathrm{O}_{3}$, нанесенные на высокодисперсный мезопористый кремнезем КIT-6, пропитывались нитратом серебра $\left(\mathrm{n}_{\mathrm{Ag}} / \mathrm{n}_{\mathrm{Co}}=4 / 99\right.$ и 8/99). Исследован фазовый состав исходных образцов и образцов после каталитических испытаний в конверсии синтез-газа и каталитические характеристики образцов. Изучены закономерности превращения образцов в процессе восстановления в водородсодержащем газе. Показано, что для образца $\mathrm{LaCoO}_{3}$ с ростом содержания серебра увеличивается активность и селективность по высшим спиртам с 6 до $23 \%$. Максимальное взаимодействие кобальта с серебром наблюдается при содержании $4 \%$ серебра. При большем содержании часть кобальта восстанавливается независимо от влияния серебра вследствие его более быстрой агломерации. Это приводит к более сильной аморфизации восстановленного образца и резкому росту его активности. Образец $\mathrm{LaCo}_{0.7} \mathrm{Cu}_{0.3} \mathrm{O}_{3}$ проявляет более высокую селективность по высшим спиртам (36 \%) благодаря влиянию меди. Промотирование образца серебром позволяет достичь максимальной селективности по высшим спиртам в 56 \% при содержании серебра в 4 \%. Дальнейшее увеличение содержания серебра приводит к резкому снижению селективности по высшим спиртам (41 \%) и появлению $\mathrm{CO}_{2}$ вследствие насыщения медьсодержащих частиц серебром и снижению взаимодействия кобальта с медью.
\end{abstract}

Ключевые слова: конверсия синтез-газа, синтез высших спиртов, промотированные серебром La-Со-катализаторы.

Благодарности. Работа поддержана Министерством науки и высшего образования Российской Федерации в рамках государственного заказа для Института катализа имени Борескова (проект AAAA-A21-121011390054-1). Исследования XRD, AES проводились с использованием средств совместного исследовательского центра «Национальный центр исследований катализаторов» в Институте катализа им. Борескова. Авторы благодарны к.Х.н. Ю.Н. Беспалко за помощь в работе. 


\section{Introduction}

Conversion of syngas obtained via the processing of biomass or conversion of carbon dioxide [1, $2,3]$ into various valuable chemical products (hydrocarbons, higher alcohols) will make it possible to abandon the use of natural fuel. Cobalt catalysts are the most effective for the conversion of syngas. Promotion of cobalt-containing catalysts is an important way of their modification in order to significantly reduce the reduction temperature, increase the activity, and control the selectivity for higher hydrocarbons and alcohols. The conventional promoters of these catalysts are expensive noble metals [4]. At the same time, in recent years, the possibility of using cheaper metals as promoters of cobalt-containing catalysts has been actively studied. Promotion with Group 11 metals $(\mathrm{Cu}, \mathrm{Ag}$, $\mathrm{Au}$ ) is considered as the most promising replacement for precious metals. The most effective among these metals is Ag, which provides a significant increase in the activity of catalysts with Ag content increase compared to $\mathrm{Au}$ and $\mathrm{Cu}$ [5]. It can be explained by the formation of a larger amount of the metastable $\beta$-Co phase with a hexagonal close-packed lattice during reductive activation in an Agcontaining catalyst [6]. In this case, a high content of $\mathrm{Cu}$ and Au leads to a decrease in the activity of the catalyst, which is caused by the coating of the edges of cobalt clusters with a promoter [5]. Silver has a fundamentally different atomic structure in comparison with copper, gold and platinum, and promotion with silver has little effect on selectivity, but a significant content leads to a decrease in activity [7].

It was shown with DFT method [8], that the rate of syngas conversion over Co-containing catalysts is controlled by $\mathrm{CO}$ dissociation and oxygen removal through the formation of water. Silver promotion of the cobalt surface decreases the rate of structure-sensitive $\mathrm{CO}$ dissociation and structure-sensitive reaction of subsequent hydrogenation. It leads to a longer lifetime of the intermediate $\mathrm{CH}_{\mathrm{x}}$ compounds and, accordingly, to an increase in the probability of chain growth. In this case, the rate of oxygen removal in the presence of silver increases [9]. It has been shown [10] that the process of oxygen hydrogenation on silver includes a fast stage of the formation of adsorbed hydroxyl groups, which are then slowly removed in the form of water. It can be assumed that, in the case of the formation of silver clusters on the surface of cobalt clusters, silver can both facilitate the incorporation of an associatively adsorbed $\mathrm{CO}$ molecule into $\mathrm{CH}_{\mathrm{x}}-\mathrm{Co}$ followed by hydrogenation and lead to termination of the $\mathrm{CH}_{\mathrm{x}}$-Co chain. In both cases, an increase in selectivity to alcohols will be observed.

A combination of $\mathrm{Ag}$ and other metals promotion of Co-containing catalysts may give an interesting result. Thus, promotion with lanthanum [11] improves the overall reducibility of cobalt and the surface area of the cobalt, which leads to an increase in the overall catalytic activity. Introduction of lanthanum into the catalytic system makes it possible to suppress the formation of carbon dioxide, as in the case of the $\mathrm{Fe}-\mathrm{Cu}-\mathrm{La}$ sample [12] and perovskite $\mathrm{LaCo}_{0.7} \mathrm{Ni}_{0.3} \mathrm{O}_{3}$ [13]. It turns out to be important in the case of the promotion of a cobalt-containing catalyst with copper, which, together with the presence of lanthanum, leads to a significant increase in the selectivity for higher alcohols [14, 15]. In this case, copper-containing catalysts are conventional catalysts for a water-gas shift reaction, which inevitably leads to $\mathrm{CO}_{2}$ formation.

In the present paper, we studied the effect of silver promotion of oxide precursors $\mathrm{LaCoO}_{3}$ and $\mathrm{LaCo}_{0.7} \mathrm{Cu}_{0.3} \mathrm{O}_{3}$ of a perovskite-type structure, supported on KIT- 6 silica, on the activity and selectivity for higher alcohols in the conversion of syngas. It was proposed, that the inclusion of lanthanum, 
cobalt, and copper cations in the perovskite structure would ensure their strong interaction at the stage of sample reduction and provide the best synergistic effect.

\section{Experimental}

The oxide samples were synthesized with the citrate method by mixing metal nitrates, citric acid, water, alcohol, and KIT-6 silica, described elsewhere [16]. KIT-6 silica was partially removed by leaching in $\mathrm{NaOH}$ solution [17]. The synthesized samples were characterized by chemical analysis (Optima 4300 DV, Perkin Elmer), X-ray diffraction (D8, Bruker), and thermal analysis (Netzsch STA 409) in an $\mathrm{Ar}+\mathrm{H}_{2}$ mixture (1/1). The resulting finely dispersed samples were divided into 3 portions, two of them were impregnated with an aqueous solution of silver nitrate based on the atomic ratio $\mathrm{Ag} / \mathrm{Co}=4 / 99$ and 8/99 according to the established cobalt content in the sample. Then the samples were dried in air in a place protected from direct sunlight with occasional thorough mixing.

Catalytic tests with a duration of $18-19 \mathrm{~h}$ were performed in a periodic mode in a flow laboratory reactor at a temperature of $240^{\circ} \mathrm{C}$, a pressure of $2 \mathrm{MPa}$, and the following gas composition: $\mathrm{CO} / \mathrm{H}_{2}=1 / 2$ and $10 \%$ nitrogen (an internal standard). A powder with a grain size of $0.14-0.25 \mathrm{~mm}$ was prepared from the sample. The reductive activation of the samples before catalytic measurements was carried out in a flow of an $\mathrm{H}_{2} / \mathrm{Ar}$ mixture at temperature $500{ }^{\circ} \mathrm{C}$ for $\mathrm{LaCoO}_{3}$ sample and $330{ }^{\circ} \mathrm{C}$ for $\mathrm{LaCo}_{0.7} \mathrm{Cu}_{0.3} \mathrm{O}_{3}$ sample, based on the results of DTA. GHSV was selected in such a way that CO conversion was not high and close for all the samples, that is, the tests took place under similar conditions. The composition of the gaseous products was analyzed continuously. Liquid products were collected and analyzed after the reaction.

\section{Results and discussion}

According to XRD data, the synthesized samples $\mathrm{LaCoO}_{3} / \mathrm{KIT}-6$ и $\mathrm{LaCo}_{0.7} \mathrm{Cu}_{0.3} \mathrm{O}_{3} / \mathrm{KIT}-6$ consist of a phase with a perovskite structure with a rhombohedral lattice $\mathrm{R} \overline{3} \mathrm{c}\left(\mathrm{LaCoO}_{3}-\mathrm{ICDD}\right.$ PDF2 00 048-0123) (Fig. 1). It should be noted that the samples consist of only one phase; no cobalt or copper oxides are observed.

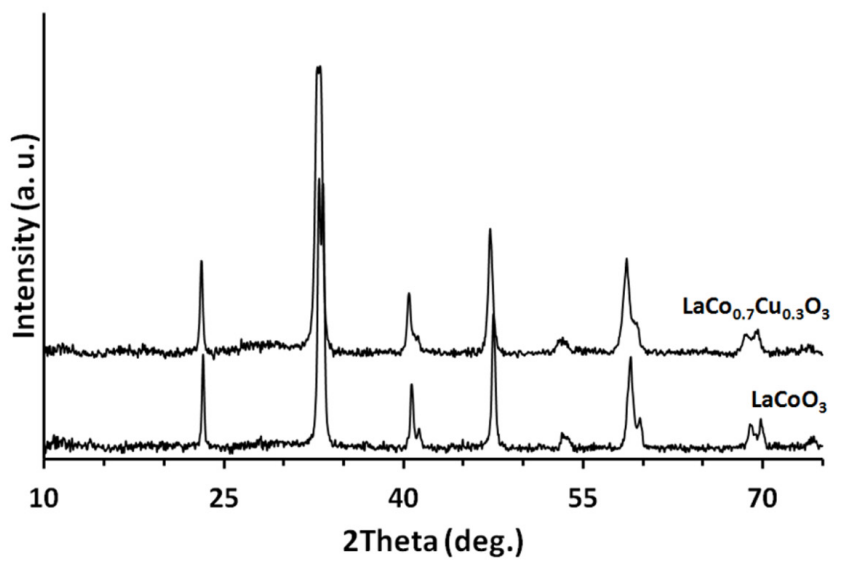

Fig. 1. Diffraction patterns of initial samples $\mathrm{LaCoO}_{3} / \mathrm{KIT}-6$ and $\mathrm{LaCo}_{0.7} \mathrm{Cu}_{0.3} \mathrm{O}_{3} / \mathrm{KIT}-6$. All reflexes belong to the perovskite phase 
The transformations during reductive activation were investigated by thermal analysis. According to thermal analysis in the $\mathrm{Ar}+\mathrm{H}_{2}$ mixture data (Fig. 2) for all samples, a weight loss effect is observed in the region of $130^{\circ} \mathrm{C}$, corresponding to the removal of adsorbed water. In the case of $\mathrm{LaCoO}_{3}$ reduction, three exothermic effects are observed: 357,478 , and $677^{\circ} \mathrm{C}$. The first two peaks refer to sequential cobalt reduction: $\mathrm{Co}^{3+} \rightarrow \mathrm{Co}^{2+}$ and $\mathrm{Co}^{2+} \rightarrow \mathrm{Co}^{0}[18]$. The mass loss values for these two stages of cobalt reduction turn out to be close, although they should correlate as $1 / 2$. The close value of the weight loss with a thermal effect of $677^{\circ} \mathrm{C}$ indicates that this effect is related to the reduction of a part of the cobalt at this temperature. An increase in the temperature of $\mathrm{Co}^{2+}$ reduction to $677{ }^{\circ} \mathrm{C}$ may be due to the influence of the support, which leads to the formation of hardly reducible cobalt silicate $\mathrm{Co}_{2} \mathrm{SiO}_{4}$ [19]. Promotion of $\mathrm{LaCoO}_{3}$ with silver nitrate slightly changes the pattern of cobalt reduction. The main effect is traced in a decrease in the temperature of the first stage of reduction of cobalt $\mathrm{Co}^{3+} \rightarrow \mathrm{Co}^{2+}$ and its prolongation. In this case, an increase in the silver content leads to a stronger shift towards lower temperatures. The second thermal effect during the promotion of $\mathrm{LaCoO}_{3}$ with silver also shifts somewhat to the region of lower temperatures. It can be assumed that the optimal silver content, at which the maximum interaction of cobalt with silver is ensured, is located near the $\mathrm{n}_{\mathrm{Ag}} / \mathrm{n}_{\mathrm{Co}}=4 / 99$ region, which is consistent with the data of other authors. [5]. In the samples promoted with silver, some of the $\mathrm{Co}^{2+}$ cations are also reduced at temperatures above $600{ }^{\circ} \mathrm{C}$ due to the formation of cobalt silicate, which is a result of the deep interaction of the perovskite phase with KIT-6 silica and its partial incorporation into the perovskite structure [16].

A similar picture is observed for the $\mathrm{LaCo}_{0.7} \mathrm{Cu}_{0.3} \mathrm{O}_{3}$ samples. Most of the cations of cobalt and copper are reduced together at a temperature of $266^{\circ} \mathrm{C}$ with the formation, probably, of bimetallic

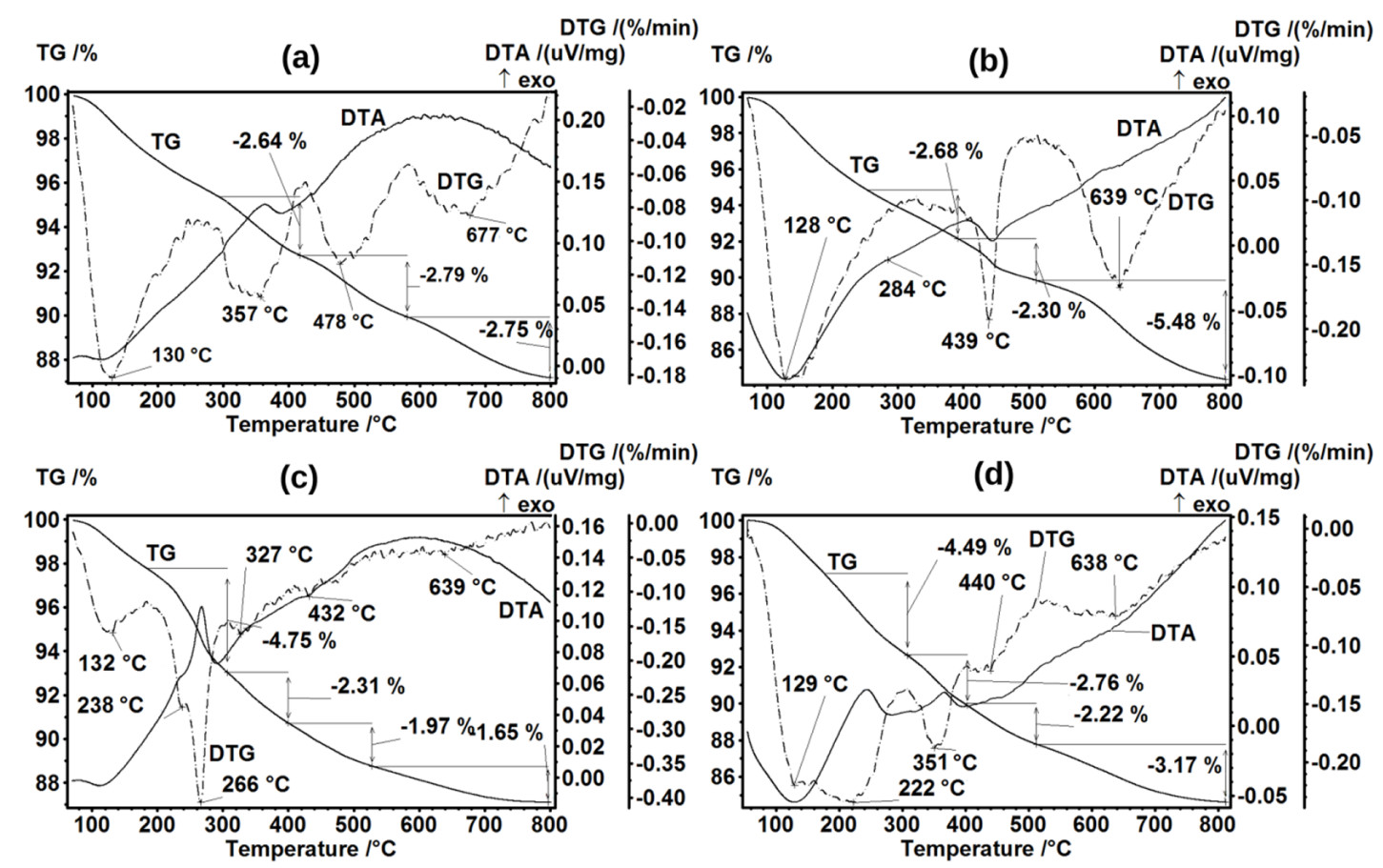

Fig. 2. DTA data of samples in a hydrogen-containing mixture: (a) $\mathrm{LaCoO}_{3} / \mathrm{KIT}-6$, (b) $4 \% \mathrm{Ag} / \mathrm{LaCoO}_{3} / \mathrm{KIT}-6$, (c) $\mathrm{LaCo}_{0.7} \mathrm{Ti}_{0.3} \mathrm{O}_{3} / \mathrm{KIT}-6$, (d) $4 \% \mathrm{Ag} / \mathrm{LaCo}_{0.7} \mathrm{Ti}_{0.3} \mathrm{O}_{3} / \mathrm{KIT}-6$ 
$\mathrm{Cu}-\mathrm{Co}$ particles. However, some of the copper and cobalt cations are reduced separately: for copper cations $-238^{\circ} \mathrm{C}$; for cobalt cations $-327,432,639^{\circ} \mathrm{C}$. The reduction temperatures of cobalt cations are close to the reduction temperatures in the case of the silver-promoted $\mathrm{LaCoO}_{3}$ sample. The separate reduction of cobalt and copper cations is apparently related to the cations located on the surface of the perovskite phase. A low proportion of separately reducible cobalt cations leads to a weakly pronounced thermal effect of the reduction of cobalt at temperatures above $600{ }^{\circ} \mathrm{C}$ caused by the formation of cobalt silicate. The promotion of copper-containing perovskite with silver significantly changes the nature of the reduction of the samples. So, in the case of a silver content of $4 \%$, the reduction of copper with cobalt starts at a temperature of less than $200{ }^{\circ} \mathrm{C}$ with a maximum at $222{ }^{\circ} \mathrm{C}$. Thermal effects are observed corresponding to the separate reduction of some of the cobalt cations: 351 , about 440 and $638^{\circ} \mathrm{C}$. Probably due to the close surface tension [20] of copper and silver, a similar crystal lattice $(\mathrm{Fm} \overline{3} \mathrm{~m})$ and the possibility of the formation of binary alloys of any composition [21] silver modifies the surface of the formed $\mathrm{Cu}-\mathrm{Co}$ particles with suppression of the complete reduction of cobalt. With a further increase in the silver content $(8 \%)$, in addition to the analogous stage of the combined reduction of copper with cobalt, thermal effects of the separate reduction of cobalt from copper are also observed. In this case, the first stage of cobalt reduction occurs at a temperature of about $300^{\circ} \mathrm{C}$. We believe that the maximum silver content that can be associated with the forming $\mathrm{Cu}-$ Co particles in this system is in the range from $4 \%$ to $8 \%$. With a further increase in the silver content to $8 \%$, some of the silver is unbound with such particles and can affect the reduction of the remaining cobalt cations, lowering the observed reduction temperature, similar to the reduction of cobalt in the $4 \% \mathrm{Ag} / \mathrm{LaCoO}{ }_{3}$ sample.

According to the observed regularities of the reduction of samples with hydrogen, one should expect that in the case of the separate reduction of cobalt cations from the reduction of silver and copper, in addition to the particles of cobalt modified by copper and / or silver, an unmodified cobalt particles will also appear. Such samples should have a higher activity in syngas conversion. This is due to the fact that silver on the surface of cobalt particles occupies the most active centers, reducing the overall activity of such particles, while, however, contributing to an increase in the selectivity for alcohols, an increase in the chain length, and a decrease in the selectivity for light hydrocarbons [9]. To reduce the samples, a temperature was chosen that ensures the complete reduction of cobalt, with the exception of the forming phase of cobalt silicate. It was $500{ }^{\circ} \mathrm{C}$ for samples based on $\mathrm{LaCoO}_{3}$ and $330{ }^{\circ} \mathrm{C}$ for samples based on $\mathrm{LaCo}_{0.7} \mathrm{Cu}_{0.3} \mathrm{O}_{3}$.

The results of catalytic tests of the samples in syngas conversion are consistent with the assumption made above. Thus, in the case of $\mathrm{LaCoO}_{3}$, with an increase in the silver content, the activity and selectivity for alcohols increases significantly (Table 1) with a simultaneous decrease in the selectivity for paraffins. The constant value of the distribution parameter of alcohols $\alpha$ indicates that $\mathrm{CH}_{\mathrm{x}}$ hydrocarbon particles are formed on cobalt particles, and silver clusters are responsible for their termination by the introduction of an associatively adsorbed CO molecule. Correspondingly, with an increase in the silver content, the selectivity for alcohols increases. The fraction of alcohols is represented in the overwhelming majority of primary alcohols, which excludes the possibility of their synthesis by hydration of olefins.

In the case of the $\mathrm{LaCo}_{0.7} \mathrm{Cu}_{0.3} \mathrm{O}_{3}$ sample, the promotion with silver decreases the activity of the samples, probably due to a decrease in the activity of copper-containing metal particles, including the 
Table 1. Catalytic properties of samples on mesoporous silica KIT- 6 in the syngas conversion at pressure of $2 \mathrm{MPa}$ and $240{ }^{\circ} \mathrm{C}$ and gas composition $\mathrm{H}_{2} / \mathrm{CO}=2 / 1$

\begin{tabular}{|c|c|c|c|c|c|c|c|c|c|c|c|c|c|c|}
\hline \multirow[b]{2}{*}{ Sample } & \multirow{2}{*}{$\begin{array}{l}\mathrm{n}_{\mathrm{Ag}} / \\
\mathrm{n}_{\mathrm{Co}}\end{array}$} & \multirow{2}{*}{$\begin{array}{l}\mathrm{S}_{\mathrm{sa}}, \\
\mathrm{m}^{2} / \mathrm{g}\end{array}$} & \multirow{2}{*}{$\begin{array}{c}\text { GHSV, } \\
\mathrm{h}^{-1}\end{array}$} & \multirow{2}{*}{$\begin{array}{c}\mathrm{X}_{\mathrm{CO}}, \\
\%\end{array}$} & \multirow{2}{*}{$\begin{array}{c}\mathrm{S}_{\mathrm{CO}_{2}} \\
\%\end{array}$} & \multirow{2}{*}{$\begin{array}{c}\mathrm{S}_{\mathrm{CH}_{4}}, \\
\% .\end{array}$} & \multirow{2}{*}{$\underset{\mathrm{C}_{2+}}{\mathrm{S}_{\mathrm{C}}}$} & \multicolumn{3}{|c|}{$\mathrm{ROH}, \mathrm{C}_{1-6}$} & \multicolumn{4}{|c|}{$\mathrm{RH}, \mathrm{C}_{9-16}$} \\
\hline & & & & & & & & $\begin{array}{l}\mathrm{S}, \\
\%\end{array}$ & $\alpha_{\mathrm{ASF}}$ & $\mathrm{Y}$ & $\alpha_{\mathrm{ASF}}$ & $\begin{array}{l}\mathrm{S}, \\
\%\end{array}$ & $\mathrm{Y}$ & $\begin{array}{l}\text { en/ } \\
\text { an }\end{array}$ \\
\hline $\mathrm{LaCoO}_{3}$ & - & 117 & 2350 & 22.4 & 0 & 18.7 & 14.9 & 6.1 & 0.41 & 9 & 0.82 & 60.6 & 52 & 0.21 \\
\hline $4 \% \mathrm{Ag} / \mathrm{LaCoO}_{3}$ & $4 / 99$ & $-{ }^{\mathrm{a}}$ & 2480 & 24.8 & 0 & 17.1 & 11.6 & 13.0 & 0.39 & 25 & 0.83 & 58.3 & 64 & 0.12 \\
\hline $8 \% \mathrm{Ag} / \mathrm{LaCoO}_{3}$ & $8 / 99$ & $-\mathrm{a}$ & 3340 & 22.5 & 0 & 19.0 & 12.2 & 23.2 & 0.40 & 57 & 0.81 & 45.6 & 205 & 0.11 \\
\hline $\mathrm{LaCo}_{0.7} \mathrm{Cu}_{0.3} \mathrm{O}_{3}$ & - & 193 & 1320 & 19.3 & 0 & 21.1 & 13.7 & 36.4 & 0.40 & 24 & 0.78 & 28.8 & 15 & 0.08 \\
\hline $4 \% \mathrm{Ag} / \mathrm{LaCo}_{0.7} \mathrm{Cu}_{0.3} \mathrm{O}_{3}$ & $4 / 99$ & $-{ }^{\mathrm{a}}$ & 940 & 15.4 & 0 & 20.8 & 13.3 & 55.8 & 0.39 & 21 & 0.78 & 10.1 & 2 & 0.13 \\
\hline $8 \% \mathrm{Ag} / \mathrm{LaCo}_{0.7} \mathrm{Cu}_{0.3} \mathrm{O}_{3}$ & $8 / 99$ & $-^{\mathrm{a}}$ & 1060 & 18.5 & 2.1 & 17.3 & 12.8 & 41.4 & 0.40 & 24 & 0.79 & 26.4 & 9 & 0.11 \\
\hline
\end{tabular}

a - the specific surface area was not measured for the samples impregnated with silver nitrate, since the method requires a thermal pretreatment, which can cause changes in the texture of the samples that are difficult to identify.

Table designations: $\mathrm{S}_{\mathrm{sa}}$ - specific surface area of samples; GHSV - gas hourly space velocity $\left(h^{-1}\right) ; \mathrm{S}$ - selectivity of CO consumption for the corresponding reaction products (\%); X - conversion of CO (\%); ROH - alcohols; RH - paraffins; $\mathrm{Y}$ - is the yield of product $\left(\mathrm{mg} / \mathrm{g}_{\mathrm{cat}} \times \mathrm{h}\right) ; \alpha_{\mathrm{ASF}}-$ the Anderson-Schultz-Flory parameter $\left(\alpha_{2-5}\right.$ for alcohols, $\alpha_{11-20}$ for paraffins); en/an olefin to paraffin ratio.

formation of bimetallic $\mathrm{Ag}-\mathrm{Cu}$ particles. In this case, the distribution parameter of alcohols for coppercontaining samples is similar to samples based on $\mathrm{LaCoO}_{3}$, which also indicates the formation of $\mathrm{CH}_{\mathrm{x}}$ particles on cobalt particles, followed by the introduction of a $\mathrm{CO}$ molecule associatively adsorbed on copper or silver into $\mathrm{CH}_{\mathrm{x}}-\mathrm{Co}$, followed by hydrogenation.

The selectivity for methane and light hydrocarbons for all samples weakly depends on the sample composition. The alcohol selectivity for silver-promoted $\mathrm{LaCoO}_{3}$ samples increases with increasing silver content. In the case of samples based on $\mathrm{LaCo}_{0.7} \mathrm{Cu}_{0.3} \mathrm{O}_{3}$, the alcohol selectivity reaches a maximum at a silver content of $4 \%$, and at $8 \%$ it significantly decreases due to the binding of all cobalt and copper to silver clusters. In this case, the promotion of cobalt with copper provides a significant increase in the selectivity for higher alcohols and, probably, in the case of the introduction of silver on the $4 \% \mathrm{Ag} / \mathrm{LaCo}_{0.7} \mathrm{Cu}_{0.3} \mathrm{O}_{3}$ sample, reaches its maximum values. This allows us to consider this sample as the most promising for the synthesis of higher alcohols by syngas conversion.

The high silver content in the sample of $8 \% \mathrm{Ag} / \mathrm{LaCo}_{0.7} \mathrm{Cu}_{0.3} \mathrm{O}_{3}$ leads to the appearance $\mathrm{CO}_{2}$ in the products of syngas conversion, that may be caused by a decrease in the strength of interaction between copper and cobalt due to the effect of silver, as indicated in the results of thermal analysis. The ratio of olefins to paraffins for all samples modified with silver is similar, but lower in comparison with the unpromoted sample of $\mathrm{LaCoO}_{3}$, indicating that silver inhibits the activity of $\beta$-hydride elimination centers leading to the formation of olefins.

The results of XRD analysis of the samples after catalytic measurements (Fig. 3) show that all samples contain lanthanum oxide $\mathrm{La}_{2} \mathrm{O}_{3}$ (ICDD PDF2 01-073-2141), lanthanum hydroxide $\mathrm{La}(\mathrm{OH})_{3}$ (ICDD PDF2 01-083-2034), cobalt carbide $\mathrm{Co}_{2} \mathrm{C}$ (ICDD PDF2 00-050-1371), metallic silver (ICDD PDF2 01-087-0717), a trace amount of cobalt silicate $\mathrm{Co}_{2} \mathrm{SiO}_{4}$ (ICDD PDF2 00-029-0506) and metallic cobalt. Cobalt metal can be present as a hexagonal-packed $\alpha$-Co phase (ICDD PDF2 00005-0727) or as a cubic-packed $\beta$-Co phase (ICDD PDF2 00-015-0806). The type of the metallic cobalt phase cannot be accurately determined due to the low intensity of the reflections in the X-ray diffraction pattern and due to the proximity of the (220) $\alpha$-Co and (111) $\beta$-Co reflections. The absence 




Fig. 3. Diffraction patterns of samples after catalytic tests. Designations: $\bullet-\mathrm{La}(\mathrm{OH})_{3}, *-\mathrm{La}_{2} \mathrm{O}_{3},--\mathrm{Co}_{2} \mathrm{SiO}_{4}$, $\circ-\mathrm{Ag},-\mathrm{Co}_{2} \mathrm{C}, \Delta-\mathrm{Co}$

of the perovskite phase indicates complete destruction of the samples during reduction and catalytic tests. The low content of cobalt carbide, which is considered to be responsible for the synthesis of alcohols $[14,15]$, in the samples may be due to both the effect of promoters: silver and copper, which slow down the rate of $\mathrm{CO}$ dissociation, and the effect of the lanthanum-containing oxide support. Cobalt silicate suggested on the basis of thermal analysis data is observed in trace amounts, which is well explained by the high amorphization of the samples after catalytic tests. The copper oxide phase is not observed, it may be the result of the formation of bimetallic particles with cobalt on its basis. Reflections of metallic silver are observed only in samples containing $8 \%$ silver, which is in excellent agreement with the thermal analysis data.

\section{Conclusions}

Silver promotion of perovskite-type oxide precursors $\mathrm{LaCoO}_{3}$ and $\mathrm{LaCo}_{0.7} \mathrm{Cu}_{0.3} \mathrm{O}_{3}$, supported on mesoporous silica KIT-6, makes it possible to increase significantly the selectivity of catalysts based on them for higher alcohols in syngas conversion. In the case of $\mathrm{LaCoO}_{3}$, the alcohol selectivity increases with an increase in the silver content from 6 to $23 \%$. Cobalt promotion with copper provides a more significant increase in the selectivity for higher alcohols, and in the case of additional promotion with silver on the $4 \% \mathrm{Ag} / \mathrm{LaCo}_{0.7} \mathrm{Cu}_{0.3} \mathrm{O}_{3}$ sample, the selectivity reaches a maximum of $56 \%$ with respect to converted $\mathrm{CO}$. In the presence of silver, the reduction temperature of cobalt and copper decreases, while the activity of copper-containing samples decreases. In the case of samples based on $\mathrm{LaCoO}_{3}$, with an increase in the silver content, its stronger interaction with a part of the initially reduced cobalt is observed, which probably leads to the formation of a part of cobalt unbound with silver and its independent reduction. This in turn significantly increases the activity of the catalyst. The promotion of cobalt-containing catalysts with silver apparently suppresses the activity of the centers responsible for the synthesis of olefins; their content in hydrocarbons does not exceed 10-12\% of the mass.

The high activity and low commercial price of silver in comparison with other noble metals makes it possible to consider silver as the most promising promoter of catalysts for the synthesis of higher alcohols in syngas conversion. 


\section{References}

1. Roy P. S., Song J., Kim K., Park C.S., Raju A.S.K. $\mathrm{CO}_{2}$ conversion to syngas through the steam-biogas reforming process. Journal of $\mathrm{CO}_{2}$ Utilization 2018. Vol. 25, P. 275-282. https://doi. org/10.1016/j.jcou.2018.04.013

2. Jeffry L., Ong M. Y., Nomanbhay S., Mofijur M., Mubashir M., Show P.L. Greenhouse gases utilization: A review. Fuel 2021. Vol. 301, P. 121017. https://doi.org/10.1016/j.fuel.2021.121017

3. Bahmanpour A. M., Signorile M., Krocher O. Recent progress in syngas production via catalytic $\mathrm{CO}_{2}$ hydrogenation reaction. Applied Catalysis B: Environmental 2021. Vol. 295, P. 120319. https://doi. org/10.1016/j.apcatb.2021.120319

4. Diehl F., Khodakov A. Y. Promotion of Cobalt Fischer-Tropsch Catalysts with Noble Metals: a Review. Oil and Gas Science and Technology 2009. Vol. 64(1), P. 11-24. https://doi.org/10.2516/ ogst:2008040

5. Jacobs G., Ribeiro M.C., Ma W., Ji Y., Khalid S., Sumodjo P.T.A., Davis B.H. Group 11 $(\mathrm{Cu}, \mathrm{Ag}, \mathrm{Au})$ promotion of $15 \% \mathrm{Co} / \mathrm{Al}_{2} \mathrm{O}_{3}$ Fischer-Tropsch synthesis catalysts. Applied Catalysis A: General 2009. Vol. 361(1-2), P. 137-151. https://doi.org/10.1016/j.apcata.2009.04.007

6. Eschemann T. O., Oenema J., De Jong K.P. Effect of noble metal promotion for $\mathrm{Co} / \mathrm{TiO}_{2}$ Fischer-Tropsch catalysts. Catalysis Today 2016. Vol. 261, P. 60-66. https://doi.org/10.1016/j. cattod.2015.06.016

7. Jermwongratanachai T., Jacobs G., Maa W., Shafer W. D., Gnanamani M. K., Gao P., Kitiyanan B., Davis B. H., Klettlinger J. L.S., Yen C.H., Cronauer D. C., Kropf A. J., Marshall C. L. Fischer-Tropsch synthesis: Comparisons between $\mathrm{Pt}$ and $\mathrm{Ag}$ promoted $\mathrm{Co} / \mathrm{Al}_{2} \mathrm{O}_{3}$ catalysts for reducibility, local atomic structure, catalytic activity and oxidation-reduction (OR) cycles. Applied Catalysis A: General 2013. Vol. 464-465, P. 165-180. https://doi.org/10.1016/j.apcata.2013.05.040

8. Filot I.A.W., Van Santen R.A., Hensen E.J.M. The Optimally Performing Fischer-Tropsch Catalyst. Angewandte Chemie International Edition in English 2014. Vol. 53(47), P. 12746-12750. https://doi.org/10.1002/anie.201406521

9. Chen W., Pestman R., Chiang F.-K., Hensen E. J.M. Silver addition to a cobalt FischerTropsch catalyst. Journal of Catalysis 2018. Vol. 366, P. 107-114. https://doi.org/10.1016/j. jcat.2018.07.028

10. Dokuchits E.V., Khasin A.V., Khassin A.A. Mechanism of the Catalytic Synthesis of Water on Silver. Mendeleev Communication 2015. Vol. 25(2), P. 155-156. http://doi.org/10.1016/j. mencom.2015.03.028

11. Shimura K., Miyazawa T., Hanaoka T., Hirata S. Fischer-Tropsch synthesis over alumina supported cobalt catalyst: Effect of promoter addition. Applied Catalysis A: General 2015, Vol. 494, P. 1-11. https://doi.org/10.1016/j.apcata.2015.01.017

12. Barama A., Bettahar M.M., Kiennemann A. Higher alcohol synthesis on iron-coppermolybdenum containing catalysts. Studies in Surface Science and Catalysis 1997. Vol. 107, P. 47-54. https://doi.org/10.1016/S0167-2991(97)80315-1

13. Tsoukalou A., Imtiaz Q., Kim S. M., Abdala P.M., Yoon S., Müller C.R. Dry-reforming of methane over bimetallic Ni-M/La $\mathrm{O}_{3}(\mathrm{M}=\mathrm{Co}, \mathrm{Fe})$ : The effect of the rate of $\mathrm{La}_{2} \mathrm{O}_{2} \mathrm{CO}_{3}$ formation and phase stability on the catalytic activity and stability. Journal of Catalysis 2016. Vol. 343, P. 208-214. https://doi.org/10.1016/j.jcat.2016.03.018

$$
-445-
$$


14. Ao M., Pham G.H., Sunarso J., Li F.P., Jin Y., Liu S.M. Effects of alkali promoters on trimetallic $\mathrm{Co}-\mathrm{Ni}$-Cu-based perovskite catalyst for higher alcohol synthesis from syngas. Catalysis Today 2020. Vol. 355(Si), P. 26-34. https://doi.org/10.1016/j.cattod.2019.06.061

15. Gobel C., Schmidt S., Froese C., Fu Q., Chen Y.T., Pan Q. S., Muhler M. Structural evolution of bimetallic $\mathrm{Co}-\mathrm{Cu}$ catalysts in $\mathrm{CO}$ hydrogenation to higher alcohols at high pressure. Journal of Catalysis 2020. Vol. 383, P. 33-41. https://doi.org/10.1016/j.jcat.2020.01.004

16. Dokuchits E.V., Larina T.V., Gerasimov E. Yu., Pochtar A. A., Minyukova T.P. Syngas conversion over perovskite-like $\mathrm{LaCu}_{\mathrm{x}} \mathrm{Ti}_{1-\mathrm{x}} \mathrm{O}_{3} / \mathrm{KIT}-6$ catalysts. Applied Catalysis A: General 2020. Vol. 608, P. 117834. https://doi.org/10.1016/j.apcata.2020.117834

17. Wang Y., Ren J., Wang Y., Zhang F., Liu X., Guo Y., Lu G. Nanocasted Synthesis of Mesoporous $\mathrm{LaCoO}_{3}$ Perovskite with Extremely High Surface Area and Excellent Activity in Methane Combustion. The Journal of Physical Chemistry C2008. Vol. 112(39), P. 15293-15298. https://doi. org/10.1021/jp8048394

18. Prado-Gonjal J., Gutierrez-Seijas J., Ansorregui I.H., Moran E., Terry I., Schmidt R. The role of degects in microwave and conventionally synthesized $\mathrm{LaCoO}_{3}$ perovskite. Journal of the European Ceramic Society 2016, Vol. 36(5), P. 1197-1206. https://doi.org/10.1016/j.jeurceramsoc.2015.12.014

19. Khassin A. A., Yutieva T. M., Kustova G. N., Plyasova L. M., Itenberg I. Sh., Demeshkina M.P., Chermashentseva G.K., $\quad$ Anufrienko V.F., Zaikovski V.I., Larina T.V., $\quad$ Molina I. Yu., Parmon V.N. Cobalt-containing catalysts supported by synthetic $\mathrm{Zn}$ - and Mg-stevensites and their performance in the Fischer-Tropsch synthesis. Journal of Molecular Catalysis A: Chemical 2001. Vol. 168(1-2), P. 209-224. https://doi.org/10.1016/S1381-1169(00)00530-6

20. Jurov V.M., Laurinas V. Ch., Guchenko S.A., Zavatskaja O.N. Dimensional effects and superficial tension of pure metals. Advances in current natural sciences 2012. Vol. 7, P. 88-93. http://www.natural-sciences.ru/ru/article/view?id=30295

21. Диаграммы состояния двойных металлических систем. Под ред. Н.П. Лякишева. М.: Машиностроение, 1996, с. 34-38. [State diagrams of binary metal systems. Under ed. N. P. Lyakishev. Moscow: Mashinostroyeniye, 1996, P. 34-38. (In Russ.)] 